\title{
ANALISIS BIAYA PENDIDIKAN DAN KONDISI SOSIAL EKONOMI ORANG TUA TERHADAP KEPUTUSAN SISWA MEMILIH SEKOLAH DI SMP NEGERI 1 KARANGREJO TAHUN AJARAN 2017/2018
}

\author{
Nafik Umurul Hadi ${ }^{1)}$, Tri Kresna Murti ${ }^{2)}$ \\ STKIP PGRI Tulungagung \\ nafikumurulhadi@gmail.com ${ }^{1)}$,pak.trikresna@gmail.com ${ }^{2)}$
}

\begin{abstract}
Karangrejo 1 Public Middle School shows that there are problems in decision making carried out by prospective students to continue their education in Karangrejo 1 Middle School. This study aims to analyze: the partial and simultaneous influence of education costs on parents' socio- economic conditions on the decision of students to choose schools in Karangrejo 1 Public Middle School 2017/2018 academic year Descriptive method with a quantitative approach. The data analysis technique used is multiple linear regression analysis. Based on the results of the study show that: (1) there is a significant influence between the cost of education on the decisions of students choosing schools in Karangrejo 1 Public Middle School with a tcount of XI Against $Y$ worth tcount (3.693)> t table (1.987). (2) there is an influence there is a significant influence between the socio-economic conditions of parents on the decision of students to choose schools in Karangrejo 1 Public Middle School with a tcount of XI Against Y worth tcount (3.352)> ttable (1.987). (3) there is an influence there is a significant influence between the cost of education and the socio-economic conditions of parents on the decision of students to choose schools in SMP 1 Karangrejo with a tcount of XI Against $Y$ worth tcount (3.352)> ttable (1.987).
\end{abstract}

Keywords: Education Costs, Parents' Socio-Economic Conditions,Students' Decisionsin Choosing Schools

\begin{abstract}
Abstrak
SMP Negeri 1 Karangrejo menunjukkan bahwa ada masalah dalam pengambilan keputusan yang dilakukan oleh calon peserta didik untuk melanjutkan pendidikannya di SMP Negeri 1 Karangrejo. Penelitian ini bertujuan untuk menganalisis: pengaruh secara parsial dan simultan biaya pendidikan kondisi sosial ekonomi orang tua terhadap keputusan siswa memilih sekolah di SMP Negeri 1 Karangrejo tahun ajaran 2017/2018 Metode deskriptif dengan pendekatan kuantitatif. Teknik analisis data yang digunakan adalah analisis regresi linier berganda. Berdasarkan hasil penelitian menunjukkan bahwa : (1) ada pengaruh yang signifikan antara biaya pendidikan terhadap keputusan siswa memilih sekolah di SMP Negeri 1 Karangrejo dengan nilai thitung dari X 1 Terhadap Y senilai thitung $(3,693)$ $>$ ttabel $(1,987)$. (2) ada pengaruh ada pengaruh yang signifikan antara kondisi sosial ekonomi orang tua terhadap keputusan siswa memilih sekolah di SMP Negeri 1 Karangrejo dengan nilai thitung dari $\mathrm{X}_{1}$ Terhadap Y senilai thitung $(3,352)>$ tabel $(1,987)$. (3) ada pengaruh ada pengaruh yang signifikan antara biaya pendidikan dan kondisi sosial ekonomi orang tua terhadap keputusan siswa memilih sekolah di SMP Negeri 1 Karangrejo dengan nilai thitung dari $\mathrm{X}_{1}$ terhadap $\mathrm{Y}$ senilai thitung $(3,352)>$ tabel $(1,987)$.
\end{abstract}

Kata Kunci: Biaya Pendidikan, Kondisi Sosial Ekonomi Orang Tua, Keputusan Siswa Memilih Sekolah. 



\section{PENDAHULUAN}

Pendidikan mempunyai peran yang sangat penting bagi kemajuan suatu bangsa. Oleh karena itu pendidikan harus terus menerus diperbaiki baik dari segi kuantitas maupun kualitas pendidikan. Adanya program pemerintah wajib belajar selama 12 tahun menujukkan bahwa pemerintah berusaha meningkatkan taraf kehidupan masyarakat. Sering berjalannya waktu dan pembangunandibidangpendidikan,peranan sekolah menengah sangatlah penting untuk menyiapkan peserta didik menjadi anggota masyarakat yang memiliki kemampuan akademik. Untuk itu peserta didik harus selektif dalam memilih sekolah.

Kotler dan Keller mengemukakan (2016:179, seperti dikutip Habibi dan Rubiyanti, 2016) perilaku studi tentang bagaimana individu atau kelompok, dan organisasi memilih, membeli, menggunakan, dan bagaimana barang, jasa, ide atau pengalaman untuk memuaskan kebutuhan dan keinginan mereka. Dalam mengambilan keputusan calon peserta didik dihadapkan dengan mempertimbangkan faktor biaya pendidikan dan faktor kondisi sosial ekonomi orang tua.

Menurut Idris (2010:93, seperti dikutip Amqul, 2015) salah satu permasalahan pendidikan adalah masalah biaya pendidikan. Sebagaimana diketahui bahwa biaya pendidikan di indonesia sangat mahal dan sangat memberatkan masyarakat Indonesia yang kebanyakan masih berada pada taraf ekonomi menengah ke bawah.

Kondisi sosial ekonomi orang tua sangat memiliki andil yang besar dalam setiap keputusan yang akan diambil oleh anak, tidak terkecuali untuk pendidikan. Di tengah krisis ekonomi yang seperti ini, yang banyak dirasakan pada setiap orang tua adalah tingginya biaya pendidikan dan setiap tahun biaya pendidikan yang semakin meningkat. Ketika seorang anak memutuskan untuk memilih sekolah, keputusan yang diambil bukan semata-mata berdasarkan pertimbangan diri sendiri, tetapi juga melihat bagaimana kondisi sosial ekonomi orang tua dan bagaimana orang tua mereka memandang pendidikan tersebut suatu hal yang penting atau tidak. Jadi orang tua memiliki peran penting dalam setiap keputusan yang akan diambil oleh anak. Sikap orang tua juga memiliki pengaruh yang sangat menentukan terhadap tingkah laku anak. Pendapatan ekonomi orang tua tentu saja menjadi suatu hal yang menentukan keputusan siswa memilih sekolah. Oleh karena itu , lembaga pendidikan sebagai wadah penyelenggara pendidikan harus bisa mengolah/mengatur biaya pendidikan dengan baik.

SMP Negeri 1 Karangrejo merupakan lembaga pendidikan yang biaya pendidikan termasuk dapat dijangkau oleh kalangan masyarakat yang berekonomi menengah kebawah. Oleh karena itu, masyarakat sekitar memilih menyekolahkan anaknya di SMP Negeri 1 Karangrejo. Namun bukan berarti biaya pendidikan yang mudah dijangkau oleh masyarakat luas sekolah menengah pertama ini tidak memiliki kualitas pelayanan, fasilitas dan standar pendidikan yang baik. Dari pengamatan yang peneliti amati, fasilitas yang diberikan pihak sekolah juga cukup lengkap, seperti LCD Proyektor, Laboratorium Kompuer, Perpustakaan, dan lain-lain. Hal ini didukung oleh program pemerintah yang memberikan kemudahan bagi masyarakat melalui Bantuan Operasional Sekolah (BOS) yakni menggratiskan biaya pendidikan untuk tingkat SMP. Selain itu pemerintah menyetarakan seluruh lembaga pendidikan agar tidak ada lembaga pendidikan yang dipandang sebelah mata oleh masyarakat luas. Hal ini dilakukan mulai dari Sekolah Dasar, Sekolah Menengah Pertama maupun Sekolah Menengah Atas/Sekolah Menengah Kejuruan agar tidak membeda-bedakan 
lembaga pendidikan yang mana untuk golongan ekonomi kelas tinggi, golongan ekonomi menengah ataupun golongan ekonomi rendah. Oleh karena itu pemerintah memberikan peraturan yang mana setiap sekolah harus mengutamakan calon peserta didik baru yang tempat tinggalnya dekat dengan sekolah tersebut. Namun kenyataanya dengan menerapkannya peraturan dari pemerintah itu SMP Negeri 1 Karangrejo jumlah penerimaan peserta didik baru masih belum mengalami peningkatan yang signifikan. Hal ini dibuktikan bahwa kesempatan ini masih belum dimanfaatkan oleh masyarakat. Terlihat dari tabel data penerimaan peserta didik baru di SMP Negeri 1 Karangrejo yang menunjukkan tidak adanya peningkatan yang signifikan. Kenaikan signifikan hanya terjadi pada tahun 2013/2014 yaitu sebesar 65(selisih). Tentu hal ini dapat menjadi bahan evaluasi bagi pihak sekolah tentang keputusan siswa- siswi untuk bersekolah di SMP Negeri 1 Karangrejo.

Dari fenomena yang ada di masyarakat seperti latar belakang diatas maka, peneliti ini berusaha mengetahui variabel biaya pendidikan dan kondisi sosial ekonomiorangtuaterhadapkeputusansiswa m emilih sekolah di SMP Negeri 1 Karangrejo, oleh karena itu peneliti mengambil judul "Pengaruh Biaya Pendidikan dan Kondisi Sosial Ekonomi Orang Tua Terhadap Keputusan Siswa Dalam Memilih Sekolah Di Sekolah SMP NEGERI 1 KARANGREJO Tahun Ajaran 2017/2018".

Rumusan masalah penelitian ini adalah: (1) Apakah ada pengaruh biaya pendidikan terhadap keputusan siswa memilih sekolah di SMP Negeri 1 Karangrejo tahun ajaran 2017/2018 ?. (2) Apakah ada pengaruh kondisi sosial ekonomi orang tua terhadap keputusan siswa memilih sekolah di SMP Negeri 1 Karangrejo tahun ajaran 2017/2018?.(3) Apakahadapengaruhbiaya pendidikan dan kondisi sosial ekonomi orang tua terhadap keputusan siswa memilih sekolah di SMP Negeri 1 Karangrejo tahun ajaran 2017/2018.

Tujuan penelitian ini dilakukannya adalah: (1) Untuk menganalisis pengaruh biaya pendidikan terhadap keputusan siswa memilih sekolah di SMP Negeri 1 Karangrejo tahun ajaran 2017/2018. Untuk menganalisis pengaruh kondisi sosial ekonomi orang tua terhadap keputusan siswa memilih sekolah di SMP Negeri 1 Karangrejo tahun ajaran 2017/2018. (3) Untuk menganalisis pengaruh biaya pendidikan dan kondisi sosial ekonomi orang tua terhadap keputusan siswa memilih sekolah di SMP Negeri 1 Karangrejo tahun ajaran 2017/2018.

\section{METODE PENELITIAN}

Berdasarkan judul dan tujuan penelitian, jenis penelitian ini adalah penelitian kuantitatif. Menurut Sugiyono (2015:14), metode penelitian kuantitatif merupakan metode penelitian yang berlandaskan pada filsafat positivisme, digunakan untuk meneliti populasi atau sampel tertentu, teknik pengambilan sampel pada umumnya dilakukan secara random, pengumpulan data menggunakan instrumen penelitian, analisis data bersifat kuantitatif/statistik dengan tujuan untuk menguji hipotesis yang telah diterapkan.

Rancangan penelitian kuantitatif ini merupakan rancangan penelitian non eksperimen yaitu rancangan penelitian yang memotret variable apa adanya. Dalam ha ini peneliti berupaya untuk mengambil data sesuai variable yang diteliti tanpa memanipulasi data, data tersebut akan dianalisa sejauh mana hubungan atau pengaruh variable- variabelnya. Selain itu pada rancangan penelitian non ekperimen ini peneliti tidak memberikan perlakuan (control) terhadap subyek penelitian.

Untuk mendapatkan persamaan persepsi/kejelasan pemahaman terhadap 
makna variabel yang dimaksud dalam penelitian, maka penulis menguraikan sebagai berikut :

1. Keputusan siswa memilih sekolah adalahsuatuprosesdimanakonsumen $\mathrm{m}$ engenal masalahnya, mencari mengenai produk atau merek tertentu dan mengevaluasi seberapa baik masing-masing alternatif tersebut dapat memecahkan masalahnya, yang kemudian mengarah kepada keputusan pembelian.

2. Biaya pendidikan adalah semua jenis pengeluaran yang dikeluarkan baik oleh perorangan/individu, keluarga yang menanggung anak yang sedang belajar, untuk memperoleh pendidikan yang diinginkannya.

3. Kondisi sosial ekonomi orang tua adalah keadaan yang menggambarkan kedudukan sosial ekonomi sebuah keluarga dalam lingkungan masyarakat dimana akan mempengaruhi pendidikan yang akan diperoleh oleh anggota keluarganya yakni anak. Dalam kehidupan bermasyarakat kondisi sosial ekonomi bisa dijadikan ukuran untuk menghargai seseorang.

Penelitian dilakukan di SMP Negeri 1

Karangrejo. Subjek penelitiannya adalah peserta didik kelas VIII tahun angkatan 2015/2016. Data penelitan diperoleh dari kuesioner dan dokumentasi. Sampel penelitian 89 peserta didik, pengambilan sampel menggunakan simple random sampling.

Sebelum melaksanakan analisis regresi linier berganda, maka terlebih dahulu dilakukan persyaratan linear berganda atau yang disebut uji asumsi klasik (meliputi : uji normalitas, uji linieritas, uji multikolinearitas dan uji heteroskedastisitas). Teknik analisis data yang digunakan adalah analisis regresi linier berganda selanjutnya dilakukan uji hipotesis dengan menggunakan program SPSS versi 18.0 for windows. Analisis regresi linier berganda digunakan untuk membuktikan sejauh mana pengaruh biaya pendidikan dan kondisi sosial ekonomi orang tua terhadap keputusan siswa memilih sekolah. Analisis data menggunakan uji regresi berganda, pengujian hipotesis menggunakan uji koefisien determinasi $\left(\mathrm{R}_{2}\right)$, uji parsial (uji t), dan uji simultan (uji F), sedangkan pengolahan data menggunakan Program SPSS 18.0.

\section{HASILDAN PEMBAHASAN \\ 1.Regresi Linear Berganda}

Analisis regresi linier berganda di gunakan untuk membuktikan sejauh mana pengaruh biaya pendidikan dan kondisi sosial ekonomi orang tua terhadap keputusan siswa memilih sekolah. Hasil analisis regresi linier berganda dapat di lihat pada kolom unstandardized coefficients (merupakan regresi yang dihasilkan dengan menggunakan variabel yang tidak distandarisasi) pada bagian $\mathrm{B}$ (nilai konstan) dan standart eror (nilai maksimal kesalahan yang terjadi dalam memperkirakan rata-rata populasi berdasarkan sampel), kolom b menunjukkan koefisien b yaitu nilai yang menjelaskan bahwa Y (variabel terikat) akan berubah jika $X$ (variabel bebas) diubah 1 unit.

Dari hasil uji regresi linear berganda dapat dilihat pada coefficients diperoleh persamaan $\mathrm{Y}=\mathrm{a}+\mathrm{b}_{1} \mathrm{X}_{1}+\mathrm{b}_{2} \mathrm{X}_{2}$ yang dapat dijelaskan sebagai berikut:

(a) merupakan konstanta yang besarnya 19,116 menyatakan bahwa jika variabel independent (biaya pendidikan dan kondisi sosial ekonomi orang tua) sebesar 0 (nol), maka nilai variabel dependent (keputusan siswa memilih sekolah) 
sebesar 19,116.

(b1) merupakan koefisien regresi dari $\mathrm{X}_{1}$ koefisien regresi 0,643 menyatakan bahwa setiap penambahan satu satuan variabel $\mathrm{X}_{1}$ dengan asumsi variabel lain $\left(\mathrm{X}_{2}\right)$ dianggap maka hal ini akan berpengaruh peningkatan besarnyaY sebesar 0,643.

(b2) merupakan koefisien regresi 0,351dari $\mathrm{X}_{2}$ koefisien regresi menyatakan bahwa setiap penambahan satu satuan variabel $\mathrm{X}_{2}$ dengan asumsi variabel lain $\left(\mathrm{X}_{1}\right)$ dianggap konstan maka hal ini akan berpengaruh peningkatan besarnya Y sebesar 0,351.

\section{Uji Hipotesis}

Pengujian hipotesis bertujuan untuk membuktikan hipotesis yang diajukan dalam penelitian, apakah diterima atau di tolak. Uji hipotesis dalam penelitian ini terdiri dari uji $\mathrm{t}$ dan uji $\mathrm{F}$ yang di lakukan untuk mengetahui pengaruh variabel bebas biaya pendidikan $\left(\mathrm{X}_{1}\right)$ dan kondisi sosial ekonomi orang tua $\left(\mathrm{X}_{2}\right)$ terhadap variabel terikat keputusan siswa memilih sekolah (Y) baik secara parsial maupun secara simultan.

\section{a. Hasil Uji t}

Berdasarkan hasil uji $\mathrm{t}$ dapat di ketahui bahwa variabel biaya pendidikan $\left(\mathrm{X}_{1}\right)$ diperoleh nilai t hitung > t tabel $(4,776>$ $1,987)$ dengan nilai signifikan $(0,000<0,05)$ maka Ho ditolak dan Ha diterima. Jadi dapat disimpulkan bahwa ada pengaruh biaya pendidikan terhadap keputusan siswa memilih sekolah.

Selanjutnya dapat diketahui pula bahwa variabel kondisi sosial ekonomi orang tua $\left(\mathrm{X}_{2}\right)$ diperoleh nilai $\mathrm{t}$ hitung $>\mathrm{t}$ tabel $(3,412>1,987)$ dengan nilai signifikan $(0,001$ $<0,05)$ maka Ho ditolak dan Ha diterima. Jadi dapat disimpulkan bahwa ada pengaruh kondisi sosial ekonomi orang tua terhadap keputusan siswa memilih sekolah.

\section{b. Hasil uji $\mathrm{f}$ \\ Pada menunjukkan $F_{\text {hitung }}(27,351)>F_{\text {tabel }}$ $(3,09)$ dan tingkat signifikan $0,000<0,05$ maka $\mathrm{H}_{\mathrm{o}}$ ditolak dan $\mathrm{H}_{\mathrm{a}}$ diterima. Hal ini berarti terdapat pengaruh yang signifikan antara biaya pendidikan $\left(\mathrm{X}_{1}\right)$, kondisi sosial ekonomi orang tua $\left(\mathrm{X}_{2}\right)$, dan keputusan siswa memilih sekolah (Y) secara bersama-sama.}

\section{c. Uji Koefisien Determinasi}

Analisis determinasi digunakan untuk mengetahui prosentase sumbangan pengaruh variabel independen secara bersama-sama terhadap variabel dependen. pendidikan $\left(\mathrm{X}_{1}\right)$ dan kondisi sosial ekonomi orang tua $\left(\mathrm{X}_{2}\right)$. Sedangkan sisanya $61,1 \%$ di pengaruhi oleh faktor- faktor lain yang tidak di teliti dalam penelitian.

\section{PEMBAHASAN}

1. Pengaruh biaya pendidikan terhadap keputusan siswa memilih sekolah.

Berdasarkan hasil analisis data dan uji hipotesis yang dilakukan oleh peneliti dari angket yang disebar kepada peserta didik. Diketahui biaya pendidikan berpengaruh signifikan terhadap keputusan siswa memilih sekolah. Hal ini dapat dibuktikan bahwa nilai $\mathrm{t}$ hitung $>\mathrm{t}$ tabel $(4,776>1,987)$ dengan nilai signifikan $(0,000<0,05)$ maka Ho ditolak dan Ha diterima. Variabel biaya pendidikan memberikan sumbangan efektif sebesar $28,05 \%$.

Penelitian ini mendukung penelitian sebelumnya oleh Afriyana Setyawati, Stevani, Syailendra Eka Saputra tahun 2017 dengan judul Pengaruh Motivasi, Biaya Pendidikan dan Kelompok Referensi terhadap Keputusan Memilih Program Studi Pendidikan Ekonomi STKIP PGRI Sumatera Barat. Berdasarkan hasil penelitian tersebut dapat disimpulkan bahwa Hipotesis 2, Untuk 
variabel biaya pendidikan diperoleh nilai t.

Berdasarkan pada analisis diatas dapat diketahui bahwa di atas dapat dilihat bahwa koefisien determinasi diperoleh hasil nilai $R$ Square sebesar 0,389 dengan nilai koefisien determinasi sebesar $38,9 \%$. Hal ini menunjukkan bahwa $38,9 \%$ perubahan variabel dependen keputusan siswa memilih sekolah (Y) di pengaruhi oleh perubahan variabel independen biaya 0,05 , berarti $\mathrm{Ha}$ diterima dan $\mathrm{H} 0$ ditolak dengan demikian dapat dikatakan bahwa terdapat pengaruh yang signifikan secara parsial antara biaya pendidikan terhadap keputusan memilih Program Studi Pendidikan Ekonomi STKIP PGRI Sumatera Barat. Hal ini berarti semakin memadai biaya pendidikan, maka akan ikut mendukung keputusan memilih.

\section{Pengaruh kondisi sosial ekonomi orang tua terhadap keputusan siswa memilih sekolah.}

Berdasarkan hasil analisis data dan uji hipotesis yang dilakukan oleh peneliti dari angket yang disebar kepada peserta didik. Diketahui kondisi sosial ekonomi orang tua berpengaruh signifikan terhadap keputusan siswa memilih sekolah. Hal ini dapat dibuktikan bahwa nilai $t_{\text {hitung }}(3,412)>t_{\text {tabel }}$ $(1,987)$ dengan tingkat signifikansi $0,001<$ 0,05, dengan demikian Ho ditolak dan Ha diterima, sehingga dapat dinyatakan bahwa ada pengaruh kondisi sosial ekonomi terhadap keputusan siswa memilih sekolah. Variabel kondisi sosial ekonomi orang tua memberikan sumbangan efektif sebesar $14,80 \%$.

Penelitian ini juga mendukung penelitianMuhamad AmiqulHaq\&Rediana

Setiyani tahun 2016 dengan judul Pengaruh Prestasi Belajar, Kondisi Sosial Ekonomi Orang Tua Dan Self Efficacy Terhadap Minat Melanjutkan Studi Ke Perguruan Tinggi (Studi Kasus Pada Siswa Kelas XI IPS).

Variabel kondisi sosial ekonomi orang tua $\left(\mathrm{X}_{2}\right)$ diketahui besarnya $\mathrm{t}$ adalah sebesar 4,001 pada signifikansi $0,000<0,05$. Sehingga hal tersebut menunjukan bahwa secara parsial pengungkapan kondisi sosial ekonomi orang tua berpengaruh secara signifikan terhadap minat melanjutkan studi ke perguruan tinggi pada siswa sehingga $\mathrm{Ha}$ diterima.

\section{Pengaruh biaya pendidikan dan kondisi sosial ekonomi orang tua terhadap keputusan siswa memilih sekolah.}

Berdasarkan hasil analisis data dan uji hipotesis yang dilakukan oleh peneliti dari angket yang disebar kepada peserta didik. Diketahui biaya pendidikan dan kondisi sosial ekonomi orang tua berpengaruh signifikan terhadap keputusan siswa memilih sekolah. Hal ini dapat dibuktikan bahwa hasil uji f juga diperoleh nilai $F_{\text {hitung }}(27,351)>$ $F_{\text {tabel }}(3,12)$ dengan tingkat signifikansi 0,000 $<0,05$. Hal ini membuktikan bahwa ada pengaruh biaya pendidikan dan kondisi sosial ekonomi orang tua terhadap keputusan siswa memilih sekolah. Sedangkan nilai koefisien determinasi (r2) atau $\mathrm{R}$ Square dari persamaan regresi sebesar 0,389 dengan nilai koefisiendeterminasisebesar38,9\%.Halini menunjukkan bahwa $38,9 \%$ perubahan variabel dependen keputusan siswa memilih sekolah (Y) di pengaruhi oleh perubahan variabel independen biaya pendidikan ( $\left.\mathrm{X}_{1}\right)$ dan kondisi sosial ekonomi orang tua $\left(\mathrm{X}_{2}\right)$. Sedangkan sisanya $61,1 \%$ di pengaruhi oleh faktor-faktor lain yang tidak di teliti dalam penelitian ini.

\section{PENUTUP \\ Simpulan}

Berdasarkan hasil penelitian dan pembahasan hasil penelitian yang telah dilakukan dapat disimpulkan bahwa :

1. Ada pengaruh yang signifikan biaya pendidikan terhadap keputusan siswa memilih sekolah di SMP Negeri 1 
Karangrejo tahun ajaran 2017/2018.

2. Ada pengaruh yang signifikan kondisi sosial ekonomi orang tua terhadap keputusan siswa memilih sekolah di SMP Negeri 1 Karangrejo tahun ajaran 2017/2018.

3. Ada pengaruh yang signifikan antara biaya pendidikan dan kondisi sosiall ekonomi orang tua terhadap keputusan siswa memilih sekolah di SMP Negeri 1 Karangrejo tahun ajaran 2017/2018.

\section{Saran}

Berdasarkan hasil penelitian sebagaimana telah diuraikan dalam kesimpulan diatas, maka selanjutnya peneliti menyampaikan beberapa saran sebagai berikut :

\section{BagiSiswa}

Hasil penelitian ini diharapkan dapat memberikan referensi dan informasi sebagai gambaran dalam menentukan pilihan untuk melanjutkan sekolah setelah lulus dari pendidikan sekolah dasar.

\section{BagiOrang Tua}

Hasil penelitian ini diharapkan sebagai referensi dan wawasan dalam memotivasi, mengarahkan, dan membantu anak guna terus mempunyai tekad untuk meneruskan pendidikan yang lebih tinggi. Serta memberikan wawasan kepada para orang tua bahwa agar lebih selektif dalam mengambil keputusan memilih sekolah untuk putra/putrinya. Bagi SMP Negeri 1 Karangrejo Hasil penelitian ini diharapkan dapat memberikan informasi tambahan bagi kepala sekolah beserta jajarannya dalam membuat kebijakan yang berhubungan dengan keputusan siswa dalam memilih sekolah di pendidikan menengah pertama dengan memperhatikan faktor-faktor yang mempengaruhi keputusan memilih sekolah.

\section{BagiPeneliti}

Hasil penelitian ini diharapkan dapat menambah pengetahuan serta wawasan dan dapat mengetahui secara mendalam tentang pengaruh biaya pendidikan dan kondisi sosial ekonomi orang tua terhadap keputusan siswa memilih sekolah di SMP Negeri 1 Karangrejo tahun ajaran 2017/2018. Selain itu diharapkan dapat dijadikan referensi dalam bidang penelitian sehingga banyak informasi untuk memperluas pengetahuan.

\section{DAFTAR PUST AKA}

Arikunto, Suharsimi. (2014). Prosedur Penelitian Suatu Pendekatan Praktik. Jakarta: Rineka Cipta

Habibi, R., \& Rubiyanti, R. N. (2016). Analisis Faktor Pengambilan Keputusan Mendaftar Di Sma 1 Bandung (Studi Kasus Pada Siswa Sma Bpi 1 Bandung Angkatan 2015) Factor, 3(3), 3604-3613.

Haq, M. A. (2015). Pengaruh Prestasi Belajar, Kondisi Sosial Ekonomi Orang Tua, Dan Self Efficacy Terhadap Minat Melanjutkan Studi Ke Perguruan Tinggi Pada Siswa Kelas Xi Ips Man 2 Semarang Tahun Ajaran 2014/2015.

Haq, M. A., \& Setiyani, R. (2016). Pengaruh Prestasi Belajar, Kondisi Sosial Ekonomi Orang Tua Dan Self Efficacy Terhadap Minat Melanjutkan Studi KePer guruanT inggiSiswaIps , 5(3), 1034-1045.

Katrin, I. L., Setyorini, H. . D., \& Masharyono. (2016). Pengaruh Promosi Terhadap Keputusan Pembelian Di Restoran Javana Bistro Bandung, 246-254.

Lestari, Anis. (2017). Pengaruh Pembiayaan Pendidikan Oleh Orang Tua Dan Persepsi Siswa Tentang Pendidikan Terhadap Minat Melanjutkan Pendidikan Siswa XII SMAN 1 Karangrejo Tahun Ajaran 2016/2017. 
Skripsi. Sekolah Tinggi Keguruan Dan Ilmu Pendidikan (STKIP) PGRI Tulungagung.

Priyanto, Duwi. (2012). Cara Kilat Belajar Analisis Data dengan SPSS 20.Yogyakarta: CV ANDI OFFSET Setyawati, A., Stevani, \& EkaSaputra, S.
(2017). Pengaruh Motivasi, Biaya Pendidikan Dan Kelompok Referensi Terhadap Keputusan Memilih Program Studi Pendidikan Ekonomi STKIP PGRI Sumatera Barat.

Sugiyono. (2015). Metode Penelitian

Pendidikan. Bandung: Alfabeta 